\title{
Anti-proliferative, antioxidant effects of methanol extract of Calotropis procera leaf on lung cancer cells (H1299) and its ameliorative effect on expression of CD146 on blood cells
}

Ayobami Matthew Olajuyin ${ }^{1,2^{*}}$, Adefunke Kafayat Olajuyin ${ }^{1}$, Ziqi Wang ${ }^{1}$, Xingru Zhao ${ }^{1}$, Zhiwei Xu', Quncheng Zhang ${ }^{1}$ and Xiaoju Zhang ${ }^{1 *}$

\begin{abstract}
Background: Calotropis procera leaf is one of the plants commonly utilized in phytomedicine in Nigeria. The present investigation explored the use of the extracts on cell viability and apoptosis respectively. In this study, the expression of the Cluster of differentiation 146 (CD146) in the blood of lung cancer patients on regulatory T cells (Tregs) was determined. The antioxidant and anti-proliferative effects of methanol extracts of Caloropis procera leaf on lung cancer cell H1299 were investigated.

Methods: From the flow cytometry, the expression of the CD146+ in the T cells were evaluated using the healthy patient, adenocarcinoma, squamous, and small cell lung cancer respectively. The apoptosis of granulocytes, monocytes, lymphocytes, CD4+, and Treg were determined by 7-amino-actinomycin D/Annexin V-Allophycocyanin (APC) staining during the resting stage and after $24 \mathrm{~h}$ respectively. Immunofluorescence was conducted. Cell viability assay, hydroxyl $(\mathrm{OH})$, hydrogen peroxide $\left(\mathrm{H}_{2} \mathrm{O}_{2}\right)$ and nitric oxide $(\mathrm{NO})$ scavenging radicals were conducted. Reducing power and flavonoid content of Calotropis procera were investigated. The effect of the Calotropis procera at different concentrations at $24 \mathrm{hrs}$ was determined.

Results: From the flow cytometry, the expression of the CD146+ on the T cells includes $4.60 \%$ in healthy patients, $10.10,12.20,9.80 \%$ in adenocarcinoma, squamous and small cell lung cancer. The apoptosis of granulocytes, monocytes, lymphocytes, CD4+ and Treg were determined by 7-amino-actinomycin D/Annexin V-APC staining during the resting stage and after $24 \mathrm{~h}$ which indicate that apoptosis also occurred on Treg. Immunofluorescence shows the presence of CD146 in lung cancer patient's tissues. The methanol extracts of Calotropis procera leaf have antioxidant and anti-proliferative effects. Methanol extract of Calotropis procera leaf reduced CD146 expression on blood cells at $24 \mathrm{~h}$.
\end{abstract}

\footnotetext{
* Correspondence: doctorayobami@gmail.com;

zhangxiaoju1010@henu.edu.cn

'Department of Respiratory and Critical Care Medicine, Henan Provincial

People's Hospital, People's Hospital of Zhengzhou University, 450003

Zhengzhou, Henan, China

Full list of author information is available at the end of the article
}

\section{Springer Open}

(c) The Author(s). 2021 Open Access This article is licensed under a Creative Commons Attribution 4.0 International License, which permits use, sharing, adaptation, distribution and reproduction in any medium or format, as long as you give appropriate credit to the original author(s) and the source, provide a link to the Creative Commons licence, and indicate if changes were made. The images or other third party material in this article are included in the article's Creative Commons licence, unless indicated otherwise in a credit line to the material. If material is not included in the article's Creative Commons licence and your intended use is not permitted by statutory regulation or exceeds the permitted use, you will need to obtain permission directly from the copyright holder. To view a copy of this licence, visit http://creativecommons.org/licenses/by/4.0/. 
Conclusion: Increased CD146 expression in the Treg of lung cancer patients indicates that it may be a possible target for the treatment of lung cancer by utilizing potent immunotherapy or natural products such as methanol extract of Calotropis procera leaf which may ameliorate the expression of CD146. Calotropis procera has antioxidant, inhibitory capacity on $\mathrm{H} 1299$ lung cancer cells, and the ability to scavenge $\mathrm{OH}, \mathrm{H}_{2} \mathrm{O}_{2}$, and $\mathrm{NO}$ radicals. Hence, this investigation strengthens the phyto-medicinal properties of Calotropis procera.

Keywords: Treg, CD146, Lung Cancer, Calotropis procera leaf

\section{Introduction}

Lung cancer is a fatal and deadly disease with poor prognosis [1]. It has a variation of histological subtypes, and is the most disastrous cancer globally. The major causes of lung cancer are still debatable. Particulate matter in air pollution with diameter less than $10 \mu \mathrm{m}\left(\mathrm{PM}_{10}\right)$ and $2.5 \mu \mathrm{m}\left(\mathrm{PM}_{2.5}\right)$ [2], smoking, genetic factors, infections, occupational exposure are some of the possible factors causing lung cancer. The incidence of lung cancer is increasing worldwide striking an excessive danger to human well-being [3]. It is projected that 2.09 million different circumstances of lung cancer happened worldwide in 2018, position first amid all cancer forms [4]. In some industrialized nations, such as Austria and Germany, lung cancer is one of the most common cancers [5]. In the United States lung cancer prevalence has reduced, mostly in current years, comparatively due to the outcome of active tobacco control and health tutelage and promotion agencies. Remarkably, lung cancer occurrence is comparatively little in both male and female in Africa, which may be correlated to low life expectancy [6]. Lung cancer is more widespread in men, both in global and in most countries. Lung cancer is presently the prominent reason of cancer mortality approximately $20 \%$ of all cancer mortality. Lung cancer death in China is moderately high compared to most countries. It is predictable that lung cancer death in China may rise by about $40 \%$ between 2015 and 2030 [7]. Therefore, it is important to unravel a novel biomarker and therapeutic target to ameliorate prevalence and death.

Immunotherapy specifically may be a possible strategy promising to reduce the occurrences and mortality of lung cancer [8]. However, the realization of such therapy has been inadequate up to these days, perhaps because of features of the tumor. Antitumor response of most patients is not adequate. Regulatory $\mathrm{T}$ cells (Tregs) have engrossed considerable attention, because of their important functions of immunosuppression of self-antigen response $[9,10]$. $\mathrm{T}$ cells (Tregs) denote about $4-5 \%$ of the $\mathrm{CD} 4^{+} \mathrm{T}$ cells. They are important for the avoidance of autoimmunity and preform developing roles in cancer immunology $[11,12]$. Different investigations have been conducted, which revealed an increased in the Treg in the cancer patients [13-15]. This may promote tumor progression, metastasis and poor prognosis [13].

CD146 is a multipurpose molecule that is associated to numerous molecular, biochemical, and pathophysiological processes relating to therapeutic, immune system, stem cell differentiation, signal transduction $[16,17]$ and angiogenesis $[18,19]$. Currently, different researchers discovered that CD146 overexpression meaningfully correlate with the metastasis, progression and formation of new blood vessels of some malignant tumors which was studied in prostate cancer, melanoma, ovarian carcinoma esophageal cancer, gallbladder adenocarcinoma, and lung cancer [20-26].

Calotropis procera is a very unique plant which is commonly found in Africa, Asia and Middle East. It had been widely used in alternative medicine to ameliorate and treat different diseases because of its pharmacologically active compounds revealed in the plant's parts, leaves, flowers, roots, and its milky latex [27, 28]. C. procera had been explored to comprise of some vital compounds which includes anthocyanins, trierpenoids, norditerpenic esters, organic acid, cysteine protease procerain, phenol, alkaloids, flavonoids, cardenolides [29, 30]. The phytocompounds are known to be important in eradicating and ameliorating various diseases [31]. C. procera has different parts which are known for medicinal benefits to mankind. It is useful as analgestic, antispasmodic, anti-inflammatory, antimalarial, and hepatoprotective [29, 32-34]. Hence, this investigation unravels the possible antioxidant, anti-proliferative and immunotherapeutic effects of methanol extract of $C$. procera leaf by reduction of the expression of CD146 on the Treg.

\section{Materials and methods Materials}

3-(4,5-Dimethylthiazol-2-yl)-2,5-diphenyltetrazolium bromide (MTT), dimethyl sulfoxide (DMSO), propidium iodide (PI) Rnase, The Annexin V-FITC apoptosis detection kit and Cell cycle kit were purchased from KeyGEN Biology Co. Ltd (Nanjing, China). CD146 monoclonal antibody was purchased from thermofisher scientific (USA). 


\section{Cell culture}

The human HCC cell lines H1299 was obtained from the China Center for Type Culture Collection (CTCCC, Wuhan, China). The cells were maintained in DMEM medium supplemented with $10 \%$ fetal bovine serum and $1 \%$ ampicillin and streptomycin incubated in a humified atmosphere at $37^{\circ} \mathrm{C}$ under $5 \% \mathrm{CO}_{2}$.

\section{Flow cytometry for detection of CD146}

Blood samples were collected from patients which include healthy patients, adenocarcinoma, squamous lung cancer and small cell lung cancer patients respectively and the flow cytometry was used to detect the percentage of the CD146 expression on the Treg (CD4+, $\mathrm{CD} 25+, \mathrm{CD} 127 \mathrm{dim} /-$ ) respectively. Monocytes, lymphocytes and granulocytes percentage were also determined.

\section{Determination of Apoptosis}

Blood samples were also used to the detection of the apoptosis of the lymphocytes, monocytes, granulocytes during 0 and $24 \mathrm{~h}$ respectively using the Annexin- $\mathrm{V}$ and 7AAD. The Treg apoptosis was also conducted to verify may be there was apoptosis in the Treg.

\section{Immunofluorescence of normal and lung cancer patient's tissues}

Paraffin-embedded lung tissue Secs. $(5-\mu \mathrm{m}$ thick) were deparaffinized in xylene and rehydrated in a graded ethanol series to PBS ( $\mathrm{pH}$ 7.2). Antigen retrieval was performed by pressure cooking of lung sections in citrate buffer (pH 6.0) for $15 \mathrm{~min}$. Immunofluorescence staining of lung sections was performed using primary antibodies E-caderin polyclonal antibody (20874-1-AP). After overnight incubation, slides were washed and incubated with the respective secondary antibodies, Alexa 488 (Dylight 488, Goat Anti Mouse IgG $(\mathrm{H}+\mathrm{L})$ E032210 EarthOX) conjugated secondary antibodies for $1 \mathrm{~h}$. All sections were counterstained with nuclear 4',6-diamidino-2-phenylindole (DAPI) and mounted with fluorescent mounting medium. Images were taken using a confocal laser scanning microscope (Olympus FLUOVIEW FV 1000) with an Olympus IX81 digital camera.

\section{Preparation of methanol extract of Calotropis procera leaf} C. procera leaf was harvested from Ikare-Akoko, Ondo State in Nigeria in the beginning of the rainy season. It was authenticated at the Department of Botany; University of Ibadan and the voucher specimens were deposited at the herbarium (UI00167). Clean tap water was used to eliminate dirty materials and was air dried in the laboratory for several weeks. The dried materials were ground into coarse powder. About $1 \mathrm{~kg}$ of each powdered plant materials were soaked with $2.5 \mathrm{~L}$ of methanol for $96 \mathrm{~h}$ with intermittent stirring for cold extraction. The extracts were filtered via muslin cloth and evaporated to dryness at $40{ }^{\circ} \mathrm{C}$ with rotary evaporator. The dried extracts were preserved in an air-tight container inside and frigerated until use.

\section{Determination of flavonoid content of Calotropis procera leaf}

The total flavonoid content was determined with a colorimetric method described by Jia et al. [35] with some modifications. Briefly, between 10 and $1000 \mu \mathrm{g}$ of the extract in $1 \mathrm{~mL}$ of distilled water was added to $75 \mu \mathrm{L}$ of $5 \%$ NaNO2.After five minutes, $150 \mu \mathrm{L}$ of $10 \%$ followed by $500 \mu \mathrm{L}$ of $1 \mathrm{M} \mathrm{NaOH}$ and $275 \mu \mathrm{L}$ of distilled water. The solution was properly mixed and the colour intensity of the mixture read at $510 \mathrm{~nm}$ after $15 \mathrm{~min}$ while catechin served as standard.

\section{Methanol extract of Calotropis procera leaf reduced CD146 expression on blood cells at $24 \mathrm{~h}$}

Methanol extract of $C$. procera leaf was prepared into different concentrations $0 \mathrm{ug} / \mathrm{ml}, 0.5 \mathrm{ug} / \mathrm{ml}, 1.0 \mathrm{ug} / \mathrm{ml}$ and $1.5 \mathrm{ug} / \mathrm{ml}$ respectively and used on the healthy patient blood samples for $24 \mathrm{~h}$ in $\mathrm{CO}_{2} 5 \%$ incubator. RPMI 1650 media with $10 \%$ FBS was used as the media and for the dilution of the extract. The effects of the $C$. procera on the Treg, CD146+, CD4+, monocytes, granulocytes and lymphocytes were determined respectively (Fig. 1).

\section{Determination of the reducing power}

Reducing power was investigated utilizing the protocol of according Oyaizu [36]. The concentration range was $1.0 \mathrm{~mL}$ of plant extract and catechin $(10-1000 \mathrm{ug} / \mathrm{mL})$. It was mixed with phosphate buffer $(\mathrm{pH}$ 6.6) and potassium ferricyanide. The mixture was incubated at $50{ }^{\circ} \mathrm{C}$ for $20 \mathrm{~min}$ and trichloroacetic acid $(10 \%, 2.5 \mathrm{~mL})$ was added to the mixture. A portion of the resulting mixture was mixed with ferric chloride [FeCl3] $(0.1 \%, 0.5 \mathrm{~mL})$ and the absorbance was measured at $700 \mathrm{~nm}$ in a spectrophotometer manufactured by Trulab India. Higher absorbance of the reaction mixture indicated reductive potential of the extract.

\section{Determination of $\mathrm{H}_{2} \mathrm{O}_{2}$ scavenging radical}

The capability of $C$. procera leaf extract to scavenge hydrogen peroxide was determined according to the methods of Nabavi et al. [37]. A solution of hydrogen peroxide $(40 \mathrm{mM})$ was prepared in phosphate buffer $(\mathrm{pH}$ 7.4). The concentration of hydrogen peroxide was determined by absorption at $230 \mathrm{~nm}$ using a spectrophotometer. Extracts $(0.1-1 \mathrm{mg} / \mathrm{mL})$ in distilled water were added to a hydrogen peroxide solution $(0.6 \mathrm{~mL}, 40 \mathrm{mM})$. The absorbance of hydrogen peroxide was determined after $10 \mathrm{~min}$ against a blank solution containing 


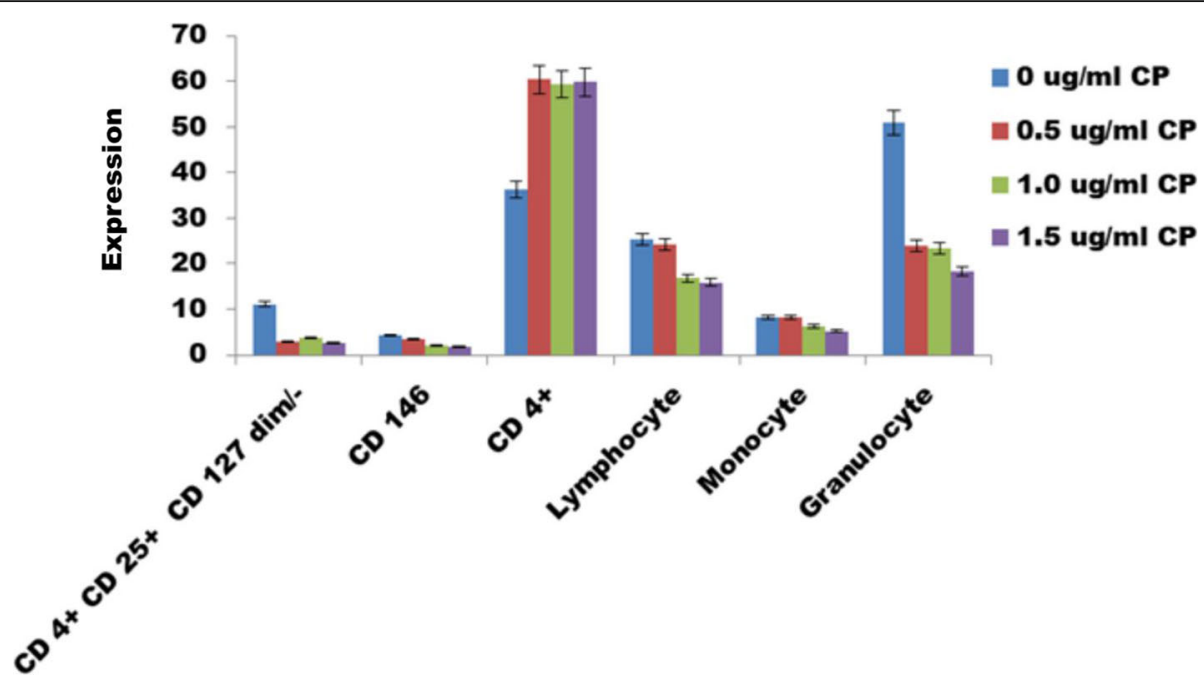

Fig. 1 Methanol extract of Calotropis procera leaf reduced CD146 expression on blood cells at $24 \mathrm{~h}$. CP was used on the blood cells and we discovered that it reduced the expression of CD146, increased the expression of CD4+ and dose dependent. It shows that CP may be an immunotherapy

phosphate buffer without hydrogen peroxide. The percentage of hydrogen peroxide scavenged by the extracts and standard was calculated as follows:

$$
\text { \%Scavenged }[\mathrm{H} 2 \mathrm{O} 2]=[(\mathrm{Ao}-\mathrm{A} 1) / \mathrm{Ao}] \times 100
$$

Where Ao is the absorbance of the control and A1 is the absorbance in the presence of the extracts or standard.

\section{Nitric oxide radical scavenging assay}

The scavenging effect of the extract on NO radical was measured according to the method of Ebrahimzadeh et al. [38]. Briefly, $1 \mathrm{~mL}$ of sodium nitroprusside $(5 \mathrm{mM})$ in phosphate buffered saline (PBS) was mixed with different concentrations of extracts and distilled water. The concentration range was $1.0 \mathrm{~mL}$ of plant extract and catechin $(10-1000 \mathrm{ug} / \mathrm{mL})$. This was incubated at room temperature for $150 \mathrm{~min}$ after which $0.5 \mathrm{~mL}$ of Griess reagent was added. The absorbance of the pink chromophore formed was read at $546 \mathrm{~nm}$ in a double beam UV visible spectrophotometer manufactured by Trulab India. Catechin was used as positive control. The percentage inhibition was calculated as:

$$
\text { \% Inhibition }=[(\text { Ao }-\mathrm{A} 1) / \mathrm{Ao}] \times 100
$$

\section{The hydroxyl scavenging radical}

The hydroxyl scavenging activity of extracts was conducted using the procedures of Halliwell [39]. The assay was performed by addition of $0.1 \mathrm{~mL}$ of EDTA, $0.1 \mathrm{~mL}$ of hydrogen peroxide ( $\mathrm{H} 2 \mathrm{O} 2), 0.36 \mathrm{~mL}$ of deoxyribose, $1.0 \mathrm{~mL}$ of plant extract $(10-1000 \mathrm{ug} / \mathrm{mL}), 0.33 \mathrm{~mL}$ of phosphate buffer (50 mM, pH 7.4) and $0.1 \mathrm{~mL}$ of ascorbic acid in sequence. The mixture was then incubated at $37^{\circ} \mathrm{C}$ for $1 \mathrm{~h}$. About $1.0 \mathrm{~mL}$ of $10 \%$ TCA and $1.0 \mathrm{~mL}$ of $0.5 \%$ TBA were added to develop the pink chromogen which was measured at $532 \mathrm{~nm}$ in a double beam UV visible spectrophotometer(Trulab India) [40].

\section{Cell viability assay}

The effects of CP on cell viability were assessed by using MTT assay. Concisely, a number of $2-5 \times 10^{-3}$ cells of H1299 per well in $100 \mathrm{~mL}$ were seeded in 96-well plates $24 \mathrm{~h}$ before the experiment and then $100 \mathrm{~mL}$ of medium with various concentrations of extract $(0,5,10,20,40$, $80 \mathrm{ug} / \mathrm{ml}$ ) added and incubated for $48 \mathrm{~h}$. Then $20 \mathrm{~mL}$ of MTT $(5 \mathrm{mg} / \mathrm{mL})$ was added to each well and incubated for an additional 2-4 h. The medium was removed and $150 \mathrm{~mL}$ DMSO was added to dissolve the formazan crystal. The absorbance of each well was measured using a Spectra Max M5 microplate spectrophotometer (Molecular Devices) at $570 \mathrm{~nm}$ wavelength. Each assay was repeated 3 times.

$$
\begin{aligned}
\text { Cell viability }(\%)= & (\text { OD sample } / \text { OD control }) \\
& \times 100 \%
\end{aligned}
$$

\section{Apoptosis}

The effect of apoptosis of CP was determined utilizing the Annexin V-FITC apoptosis detection kit. Cells were incubated with Annexin V-FITC and PI for $15 \mathrm{~min}$ in the dark then the stained cells were detected by FCM and the data were analyzed with FlowJo software. 


\section{Expression of CD 146}

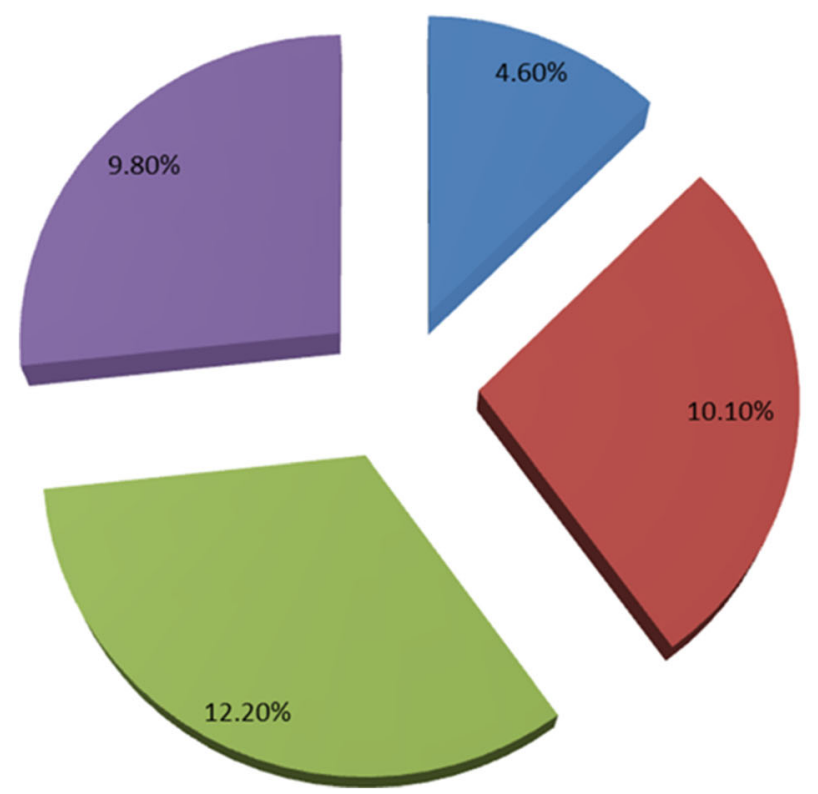

nealthy Patient

Adeno

Squamous

- SCLC

Fig. 2 CD146 expression on T cells in lung cancer patients. From the flow cytometry, the expression of the CD 146+ in the T cells includes 4.60 $\%$ in healthy patients, $10.10 \%, 12.20 \%, 9.80 \%$ in adenocarcinoma, squamous and small cell lung cancer respectively

\section{Statistical analysis}

Experimental results were expressed as mean \pm standard deviation (SD). All measurements were replicated three times. The results were analyzed with Statistical Package for the Social Sciences (SPSS) version 20 using one-way analysis of variance (ANOVA). The level of significance used was $p<0.05$.

\section{Results}

\section{CD146 in healthy and lung cancer patients' blood}

The expression of CD 146 + was significantly higher in patients than in controls $(\mathrm{P}<0.05)$. The flow cytometry was used for the investigations which showed that the expression of the CD 146 + in the T cells includes $4.60 \%$ in healthy patients, $10.10 \%, 12.20 \%, 9.80 \%$ in adenocarcinoma, squamous and small cell lung cancer respectively (Fig. 2; Table 1).

\section{Immunofluorescence of normal and lung cancer patient's} tissues

Immunofluorescence of normal and lung cancer patient's tissues indicate the presence of CD146 in the lung cancer patient's tissues (Fig. 3).

\section{Flavonoid content of Calotropis procera leaf}

The flavonoid content in the $C$. procera leaf was determined using colorimetric technique. It was found that at $1000 \mathrm{ug} / \mathrm{ml}$ of $\mathrm{CP}$, it has some flavonoid compared to catechin (standard) Fig. 4.

\section{Apoptosis was conducted to verify the cell death}

Apoptosis was conducted in the different blood cells. The cells include lymphocytes, monocytes, granulocytes, CD $4+$ and Treg. It was observed at the resting stage Fig. 5a and after $24 \mathrm{~h}$ Fig. 5b. It was verified that apoptosis also occurs in the Treg cells.

\section{Reducing power}

Figure 6 shows the dose-response curves for the reducing powers of the extract. It was found that the reducing powers of the extract increased with the increase of its concentration. The extract showed very high activity. The reducing power of extract was comparable with catechin at $1000 \mathrm{ug} / \mathrm{ml}$.

Table 1 Expression of CD146 on Treg in healthy and lung cancer patients showing number of patients

\begin{tabular}{llllc}
\hline & Healthy Patients & Adenocarcinoma & Squamous & SCLC \\
\hline Expression of CD146 in Treg (\%) & 4.60 & 10.10 & 12.20 & 7 \\
No of Patients & 11 & 9 & 5 & 7 \\
\hline
\end{tabular}




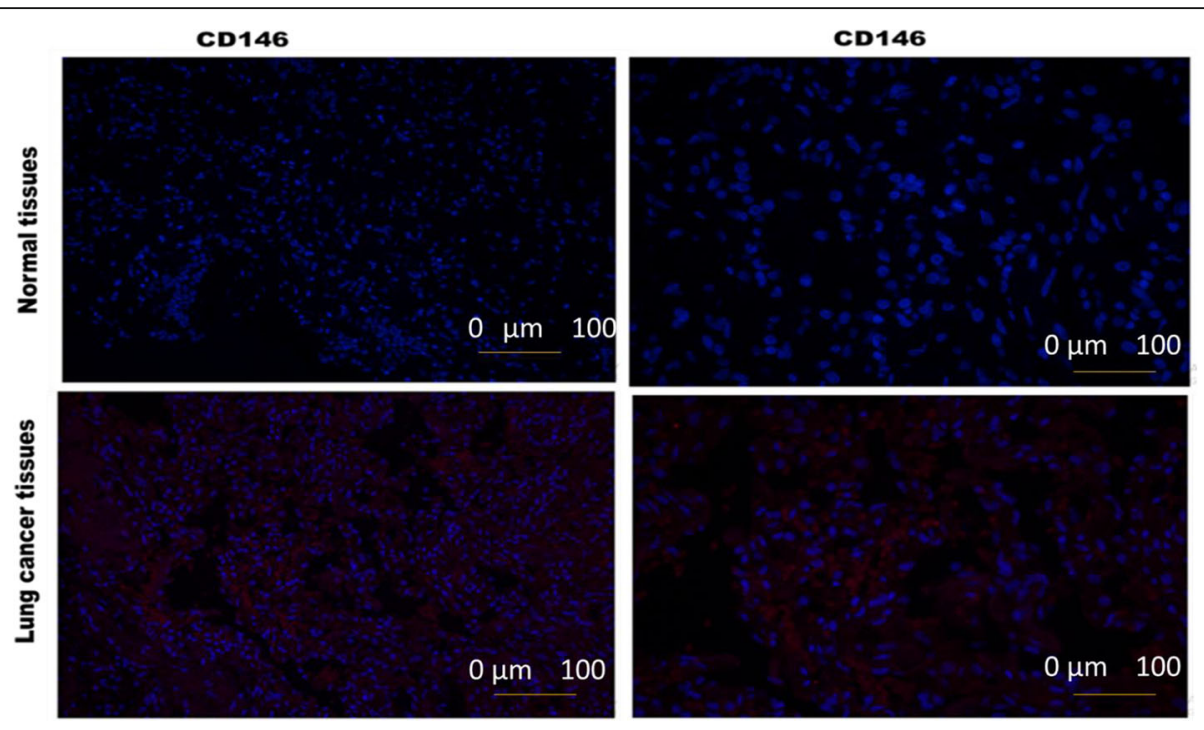

Fig. 3 CD146 expression on T cells in lung cancer patients. From the flow cytometry, the expression of the CD 146+ in the T cells includes 4.60 $\%$ in healthy patients, $10.10 \%, 12.20 \%, 9.80 \%$ in adenocarcinoma, squamous and small cell lung cancer respectively

NO Scavenging Radicals of Calotropis procera leaf The NO scavenging activities of $\mathrm{CP}$ are shown in Table 2. It elicited dose-dependent and significant scavenging of $\mathrm{NO}$ in vitro. The NO scavenging effect of $\mathrm{CP}$ was similar to that of catechin from $250-1000 \mu \mathrm{g} / \mathrm{mL}$.

\section{$\mathrm{OH}$ scavenging radicals of Calotropis procera leaf}

Table 3 shows the $\mathrm{OH}$ scavenging activity of CP. At concentration of $100 \mathrm{ug} / \mathrm{ml}, 250 \mathrm{ug} / \mathrm{ml}, 500 \mu \mathrm{g} / \mathrm{mL}, 750 \mathrm{ug} /$ $\mathrm{ml}$ and $1000 \mathrm{ug} / \mathrm{ml}$ the scavenging activities of CP was $68 \%, 70 \%, 75 \%, 77$ and $80 \%$ respectively. While that of the standard (catechin) was $61 \%, 70 \%, 76 \%, 81 \%, 85 \%$ respectively. It indicates that $\mathrm{CP}$ had $\mathrm{OH}$ scavenging radical activities similar to catechin.

\section{$\mathrm{H}_{2} \mathrm{O}_{2}$ Scavenging radical of methanol extract of Calotropis} procera leaf

Table 4 indicates that $C$. procera leaf scavenged $\mathrm{H}_{2} \mathrm{O}_{2}$ radical successfully. At concentration of $500 \mu \mathrm{g} / \mathrm{mL}, 750 \mathrm{ug} /$ $\mathrm{ml}$ and $1000 \mathrm{ug} / \mathrm{ml}$ the scavenging activities of CP was 77 , 78 and $85 \%$ respectively. The scavenging activity for the standard (catechin) was 75.7, 78.2 and $80.4 \%$ respectively. It indicates that $\mathrm{CP}$ effectively $\mathrm{H}_{2} \mathrm{O}_{2}$ scavenging radical activities at $85 \%$ which was higher than catechin.

Methanol extract of Calotropis proceraleaf reduced CD146 expression on blood cells at $\mathbf{2 4} \mathbf{h}$

The effects of the CP on the Treg, CD146+, CD4+, monocytes, granulocytes and lymphocytes were determined

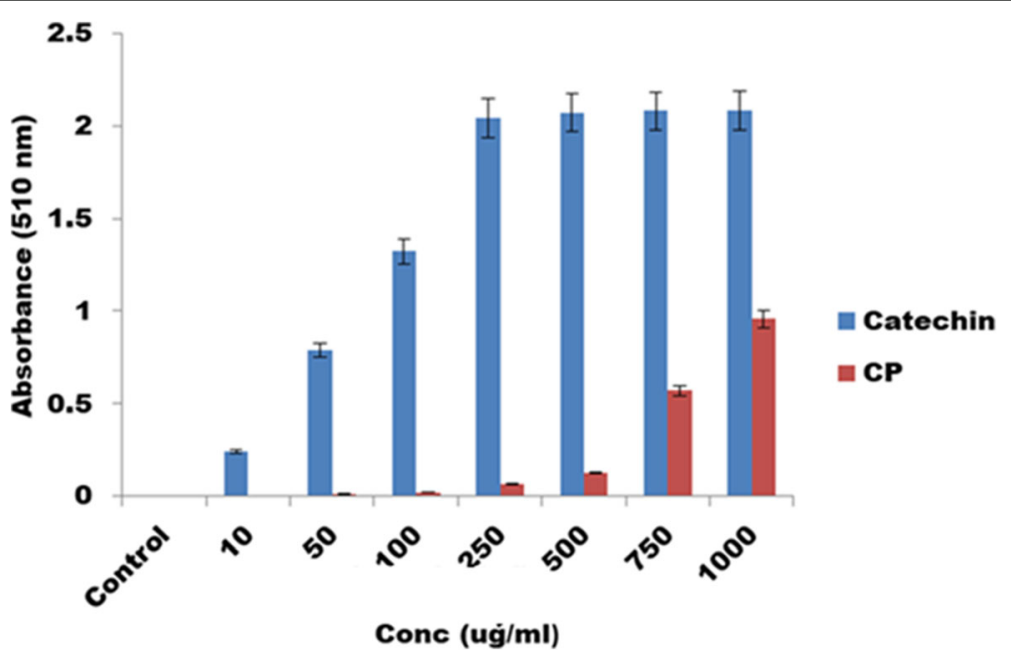

Fig. 4 Flavonoid content of Calotropis procera leaf. It revealed that at $1000 \mathrm{ug} / \mathrm{ml}$, the flavonoid content was similar to the standard catechin. Data are expressed as mean \pm SD $(n=4)$ 

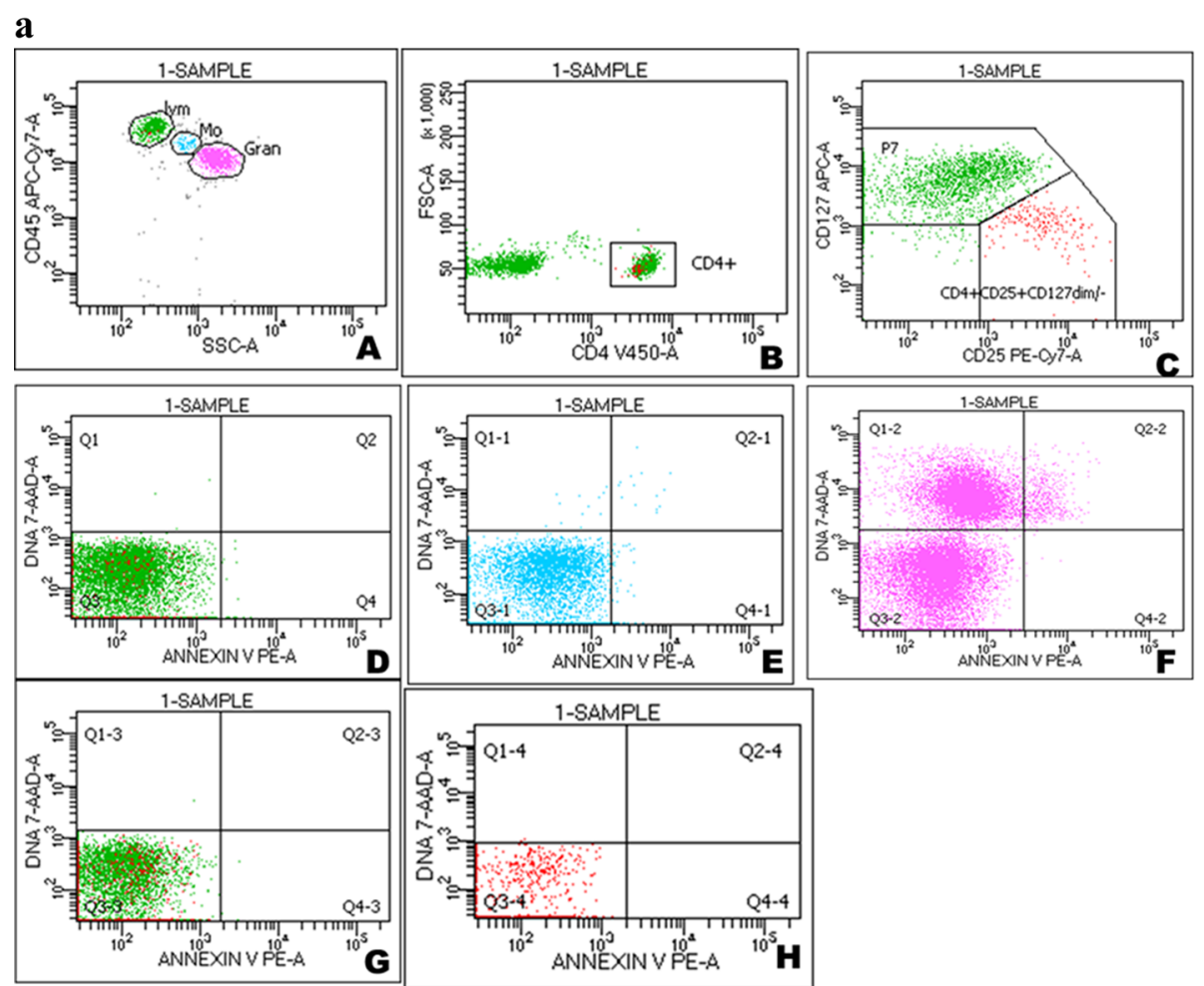

b
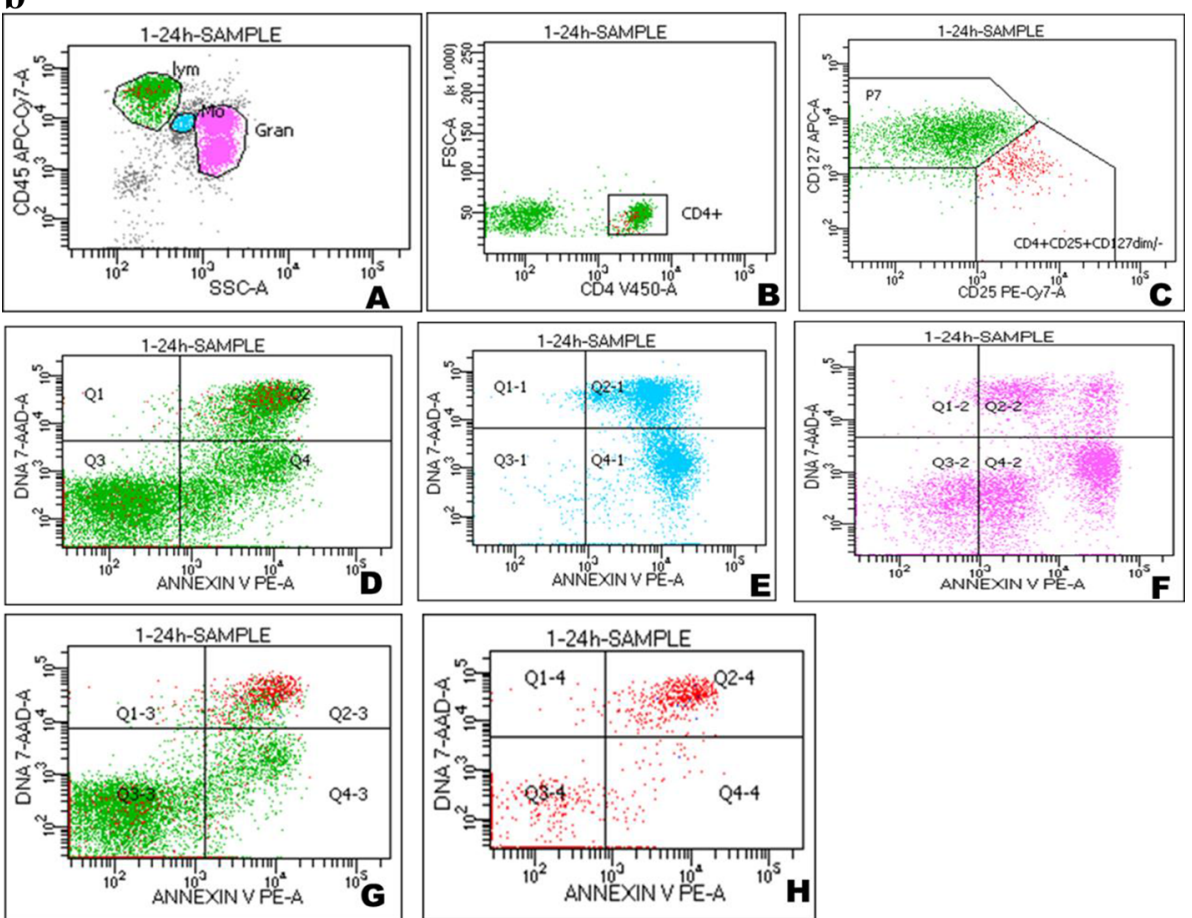

Fig. 5 a Apoptosis of lymphocyte, monocytes, granulocyte, CD4+ and Treg at 0h. A= CD45 APC-cy7-A Vs SSC-A, B=FSC-A Vs CD4 V450-A, $C=$ CD127 APC-A Vs CD25 PECy7-A, D= Apoptosis of Lymphocytes, E= Apoptosis of Monocytes, $F=$ Apoptosis of Granulocytes, $G=A p o p t o s i s ~ o f$ CD4+, $\mathrm{H}=$ Apoptosis of Treg. b Apoptosis of lymphocyte, monocytes, granulocyte, CD4+ and Treg at 24 hrs. A= CD45 APC-cy7-A Vs SSC-A, B=FSC-A Vs CD4 V450-A, C= CD127 APC-A Vs CD25 PECy7-A, D= Apoptosis of Lymphocytes, E= Apoptosis of Monocytes, $F=$ Apoptosis of Granulocytes, G=Apoptosis of CD4+, H= Apoptosis of Treg 


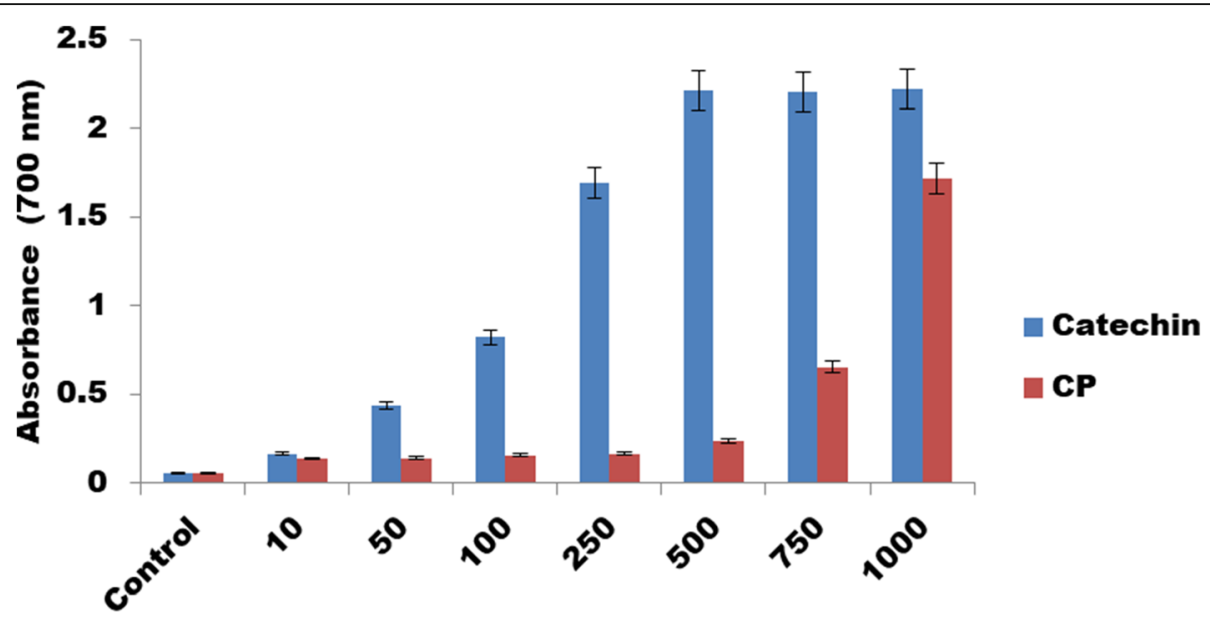

Conc (ug/ml)

Fig. 6 Reducing power assay of Calotropis procera leaf. It revealed that at $1000 \mathrm{ug} / \mathrm{ml}$, the reducing power was similar to the standard catechin. Data are expressed as mean \pm SD $(n=4)$

respectively. The result shows that $\mathrm{CP}$ at $1.5 \mathrm{ug} / \mathrm{ml} \mathrm{CD} 146$ reduced while $\mathrm{CD} 4+$ increased. Hence, $\mathrm{CP}$ may be a potent immunotherapy.

\section{MTT assay}

MTT assay was conducted to unveil the ability of Calotropis procera leaf extracts to inhibit the cell proliferation. Here, at $40 \mathrm{ug} / \mathrm{ml} \mathrm{CP}$ inhibit the cell effectively and the cell inhibition proliferation was dose dependent. Figs. 7 and 8.

\section{Discussion}

CD146 is an important molecule which is a possible biomarker and therapeutic target. It can be found in different types of cells which include lymphocytes, pericytes, immune cells, alveolar sheet and endothelial cells etc. This investigation indicates a possible means by which CD146 may be a biomarker for the detection of lung

Table 2 NO scavenging Radical of Calotropis procera leaf

\begin{tabular}{lll}
\hline Percentage Inhibition & & \\
\hline Conc (ug/ml) & Catechin & CP \\
Control & $0.00 \pm 0.00$ & $0.00 \pm 0.00$ \\
10 & $13.1 \pm 1.22^{*}$ & $2.90 \pm 0.05^{*}$ \\
50 & $26.9 \pm 2.16^{*}$ & $5.20 \pm 0.12^{*}$ \\
100 & $54.5 \pm 1.58^{*}$ & $20.0 \pm 0.80^{*}$ \\
250 & $71.5 \pm 3.28^{*}$ & $50.0 \pm 0.10^{*}$ \\
500 & $78.7 \pm 3.99^{*}$ & $70.0 \pm 0.20^{*}$ \\
750 & $88.2 \pm 2.83^{*}$ & $72.0 \pm 0.30^{*}$ \\
1000 & $82.4 \pm 3.20^{*}$ & $75.0 \pm 0.20^{*}$ \\
\hline
\end{tabular}

Data are expressed as mean \pm SD $(n=4)$; ${ }^{*}$ significantly different from control $(p<0.05)$

Where $\mathrm{CP}=$ Calotropis procera leaf cancer in patients. Here, we use the flow cytometry to determine the different percentage of CD146 in healthy, adenocarcinoma, squamous and small cell lung cancer patients. Increased in the proportion of CD146 in lung cancer patients is in line with previous investigations [41-43]. Apoptosis conducted in the study shows that it does not only occur on the CD4 + cells but apoptosis also occurs on the Treg. The immunofluorescence shows that CD146 is presence in lung cancer patient's tissues.

Flavonoid was present in the $C$. procera leaf which makes it a potential antioxidant. It has been investigated by previous researcher that $\mathrm{CP}$ may be a potential therapeutics [27]. Flavonoids are responsible for numerous varieties of pharmacological activities and involve huge collection of polyphenolic compounds having a benzo- $\gamma$ pyrone structure and universally exist in plants. They are produced by phenylpropanoid pathway $[44,45]$. In the

Table $3 \mathrm{OH}$ scavenging Radical of Calotropis procera leaf

\begin{tabular}{lll}
\hline Percentage Inhibition & & \\
\hline Conc (ug/ml) & Catechin & CP \\
\hline Control & $0.00 \pm 0.00$ & $0.00 \pm 0.00$ \\
10 & $46.1 \pm 3.22^{*}$ & $50.0 \pm 1.00^{*}$ \\
50 & $55.1 \pm 1.74^{*}$ & $60.0 \pm 1.24^{*}$ \\
100 & $61.9 \pm 0.4^{*}$ & $68.0 \pm 0.05^{*}$ \\
250 & $70.4 \pm 1.59^{*}$ & $70.0 \pm 2.66^{*}$ \\
500 & $78.6 \pm 1.19^{*}$ & $75.0 \pm 1.00^{*}$ \\
750 & $81.4 \pm 2.02^{*}$ & $77.0 \pm 0.05^{*}$ \\
1000 & $85.1 \pm 2.05^{*}$ & $80.0 \pm 0.10^{*}$ \\
\hline
\end{tabular}

Data are expressed as mean \pm SD $(n=4) ;{ }^{*}$ significantly different from control $(p<0.05)$

Where $\mathrm{CP}=$ Calotropis procera leaf 
Table $4 \mathrm{H}_{2} \mathrm{O}_{2}$ Scavenging Radical of methanol extract of Calotropis Procera leaf

\begin{tabular}{lll}
\hline Percentage Inhibition & & \\
\hline Conc (ug/ml) & Catechin & CP \\
\hline Control & $0.00 \pm 0.00$ & $0.00 \pm 0.00$ \\
10 & $13.1 \pm 1.22^{*}$ & $3.50 \pm 0.65^{*}$ \\
50 & $20.9 \pm 0.16^{*}$ & $4.20 \pm 0.22^{*}$ \\
100 & $44.5 \pm 0.58^{*}$ & $31.0 \pm 0.90^{*}$ \\
250 & $61.5 \pm 2.18^{*}$ & $55.0 \pm 0.30^{*}$ \\
500 & $75.7 \pm 1.99^{*}$ & $77.0 \pm 0.50^{*}$ \\
750 & $78.2 \pm 0.83^{*}$ & $78.0 \pm 0.20^{*}$ \\
1000 & $80.4 \pm 2.20^{*}$ & $85.0 \pm 0.10^{*}$ \\
\hline
\end{tabular}

Data are expressed as mean \pm SD $(n=4) ;{ }^{*}$ significantly different from control $(p<0.05)$

Where $\mathrm{CP}=$ Calotropis procera leaf

reducing power assay, the appearance of reductants (antioxidants) would lead to the reduction of iron (III) $\left[\mathrm{Fe}^{3+}\right]$ to iron (II) $\left[\mathrm{Fe}^{2+}\right]$ by donating an electron which serves as a significant indicator of antioxidant activity [46]. The result indicates that the C. procera leaf shows reducing power at $1000 \mathrm{ug} / \mathrm{ml}$ which is similar to that of catechin.

Nitric oxide is a very important intracellular and intercellular controller of multiple biological functions, including macrophage-mediated cytotoxicity for tumor cells, smooth muscle cells and responsible for sensory transmission $[47,48]$. Previously, nitric oxide was believed to have only advantageous characteristics, but it is now identified that overproduction of $\mathrm{NO}$ is associated with various pathological diseases, such as pulmonary hypertension, septic shock, cirrhosis, chronic inflammation, brain inflammation and cancer [49]. The NO radicals play an important role in inducing inflammatory response in the lungs and brain which can be highly toxic and their toxicity increases when they react with superoxide radicals to form peroxynitrite which harms the biomolecules [50]. $\mathrm{NO}$ is produced by three isoforms of the enzyme nitric oxide synthase (NOS), neuronal NOS, endothelial NOS, and inducible NOS (iNOS). In this investigation, the NO radical scavenging activity was based on the principle that sodium nitroprusside in an aqueous solution at physiological $\mathrm{pH}$ spontaneously generates $\mathrm{NO}$, which interacts with oxygen to produce nitrite ions that can be estimated using a Griess reagent. Scavengers of NO act against oxygen, leading to reduced production of nitrite ions which can be monitored at $546 \mathrm{~nm}$. The results indicate that the methanol extract of $C$. procera leaf tested, successfully scavenged $\mathrm{NO}$ radical in vitro; $\mathrm{CP}$ revealed dose-dependent $\mathrm{NO}$ scavenging capabilities which were similar to that of catechin in all the tested concentrations.

Hydroxyl radicals can be produced by biochemical reaction in which superoxide radical is transformed by superoxide dismutase to hydrogen peroxide, which can then produce exceedingly reactive hydroxyl radicals in the presence of divalent metal ions, such as iron and copper. Thus, elimination of the hydroxyl radical is probably one of the most active defenses of a living body against various diseases such as lung cancer. In this study, we demonstrate that $C$. procera leaf had considerable hydroxyl radical scavenging activity when compared with standard antioxidant (catechin) and could serve as an anticancer agent by inhibiting the interaction of hydroxyl radical with DNA. The result from this study indicates the effectiveness of extracts from $C$. procera leaf successfully scavenge $\mathrm{HO}$ radical in vitro. The $\mathrm{HO}$

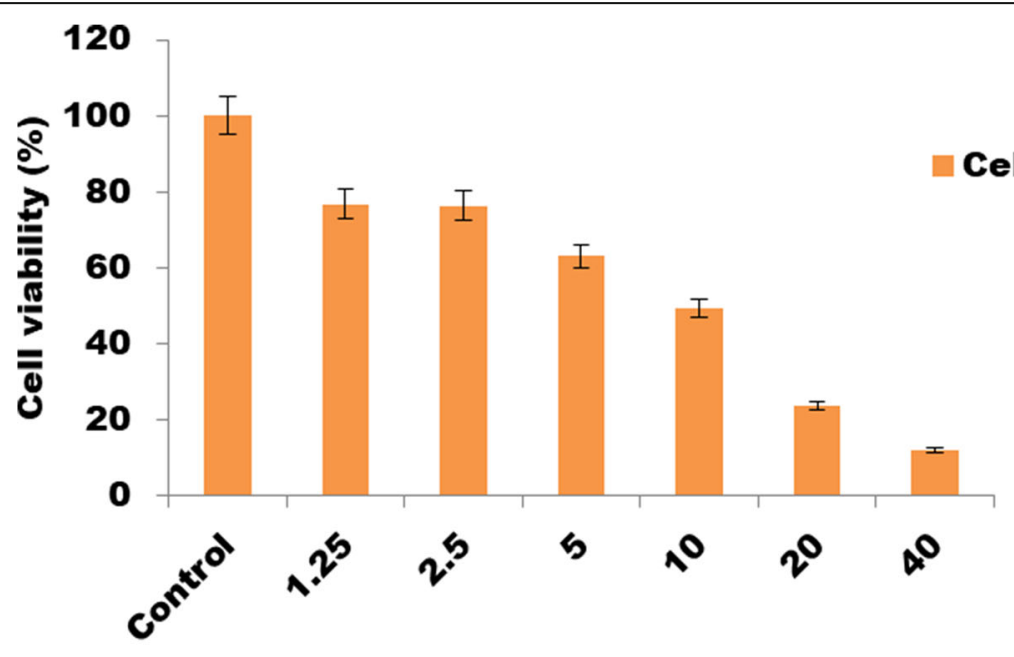

Conc (ug/ml)

Fig. 7 Cell viability of H1299 cell line using methanol extract of Calotropis procera leaf. Data are expressed as mean \pm SD $(n=3)$ 


\section{CD146 expression on Treg increased in lung cancer patients}

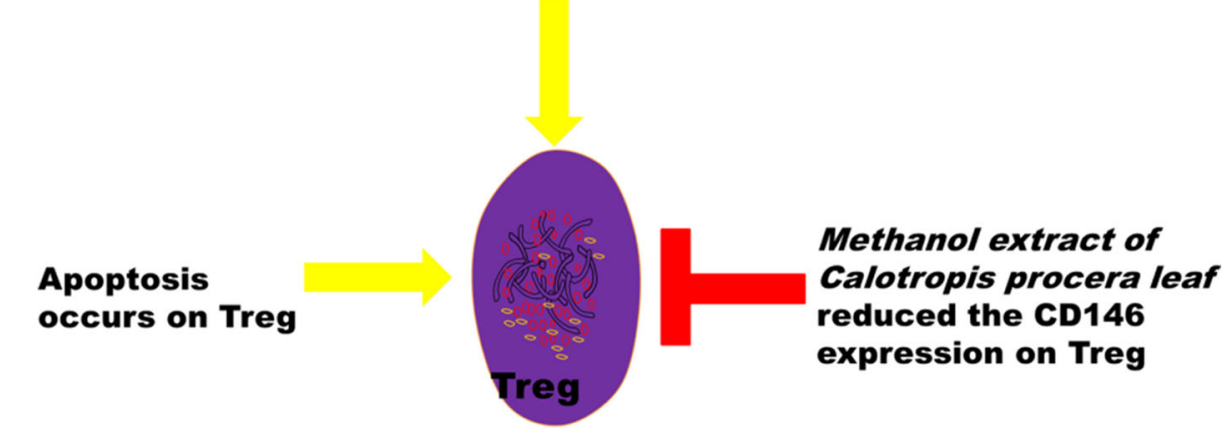

Fig. 8 Representation of Treg unveils activities of CD146, Calotropis procera and apoptosis

radical scavenging activity of $\mathrm{CP}$ was high and statistically similar to catechin. Hence, it is a very good antioxidant which may be useful to combat carcinogenesis.

Hence, we utilized the C. procera leaf on the blood cells and it unveiled that it may ameliorate the expression of CD146. This may be due to the fact that it is a good antioxidant and may have the possible immunotherapy effects for the reduction of the CD146 which may serve as a good biomarker and therapeutic target of great significance. The capability of $C$ procera to inhibit cancer cell line was unraveled utilizing H1299. Thus, H1299 was used for this study because of the prevalence of adenocarcinoma lung cancer in most of the patients admitted, which may be useful as a novel drug candidate that can be used for the treatment of the disease. The results show the anti-proliferative and hydrogen peroxide scavenging radical capability of $C$. procera. Hydrogen peroxide is a reactive oxygen radical and, at increased concentration, may become toxic and injure cells and tissues when it is changed into hydroxyl radical which can start lipid peroxidation and DNA alteration [51]. The investigation unveils the capability of the methanol extract of $C$. procera leaf to successfully scavenge $\mathrm{H}_{2} \mathrm{O}_{2}$ radical in vitro. The $\mathrm{H}_{2} \mathrm{O}_{2}$ radical scavenging activities of C. procera were similar to catechin. The cell viability shows that C. procera was able to inhibit H1299 cancer cell lines effectively and it was dose dependent which indicates that it is a potential drug candidate which could be used to ameliorate lung cancer. Hence, CP is very effective for the amelioration of cancer which can serve as an anti-cancer therapy in the nearest future.

\section{Conclusions}

Increased CD146 expression in the Treg of lung cancer patients indicate that it may be a possible target for the treatment of lung cancer by utilizing potent immunotherapy or natural products such as methanol extract of $C$ procera leaf that may ameliorate the expression of
CD146. It is also a potential biomarker and therapeutic target of clinical significance in lung cancer patients. This study establishes antiproliferative effects of $C$. procera via decrease in cell viability, and capability to scavenge $\mathrm{OH}$, $\mathrm{NO}_{2}$ and $\mathrm{H}_{2} \mathrm{O}_{2}$ radicals. Hence, this investigation strengthens the phyto-medicinal properties of C. procera. This investigation also shows that more study is required on molecular mechanisms underlying the effect of methanol extracts of C. procera, angiogenic, and other signaling pathways before isolation and characterization of active components.

\section{Abbreviations \\ CD146: Cluster of differentiation 146; CD 4+: Cluster of differentiation 4+; APC: Allophycocyanin; OH: Hydroxyl; $\mathrm{H}_{2} \mathrm{O}_{2}$ : Hydrogen peroxide; NO: Nitric oxide; PM: Particulate matter; Tregs: Regulatory T cells; MTT: 3-(4,5- Dimethylthiazol-2-yl)-2,5-diphenyltetrazolium bromide; DMSO: 4-dimethyl sulfoxide; DAPI: 5-nuclear 4',6-diamidino-2-phenylindole; FeCl3: 6-ferric chloride; NOS: 7-nitric oxide synthase}

\section{Acknowledgements}

We thank Henan Provincial People Hospital and National Natural Science Foundation for financial support and fellowship.

\section{Authors' contributions}

All the authors contributed in the preparation of this paper. AMO was responsible for data collection, analysis and drafting of the article. AKO, ZQW, ZRZ, ZWX and QCZ were responsible for blood sample and tissues collections. AMO and XJZ made substantial contributions to manuscript conception and design and participated in its critical review and final editing. All authors read and approved the final manuscript.

Funding

This work was financially supported by institutional fund of Henan Provincial People's Hospital to AMO, China Postdoctoral Foundation to AMO, the grant of the National Natural Science Foundation of China (81472835 to XJZ).

Availability of data and materials Not applicable.

\section{Declarations}

Ethics approval and consent to participate

Compliance with ethical guidelines.

Consent for publication

Not applicable. 


\section{Competing interests}

The authors declare that they have no competing interests.

\section{Author details}

'Department of Respiratory and Critical Care Medicine, Henan Provincial People's Hospital, People's Hospital of Zhengzhou University, 450003 Zhengzhou, Henan, China. ${ }^{2}$ Department of Natural and Environmental Sciences, American University of Nigeria, 98 Lamido Zubairu way Yola Bypass, P.M.B.2250, Yola Adamawa, Nigeria.

\section{Received: 19 August 2020 Accepted: 1 June 2021}

Published online: 07 June 2021

\section{References}

1. Bray F, Ferlay J, Soerjomataram I, Siegel RL, Torre LA, Jemal A. Global cancer statistics 2018: GLOBOCAN estimates of incidence and mortality worldwide for 36 cancers in 185 countries. Cancer J Clin. 2018;68(6):394-424.

2. Raaschou-Nielsen O, Beelen R, Wang M, Hoek G, Andersen ZJ, Hoffmann B et al. Particulate matter air pollution components and risk for lung cancer. Environment international. 2016;87:66-73.

3. Cao M, Chen W. Epidemiology of lung cancer in China. Thoracic cancer. 2019;10(1):3-7.

4. Siegel RL, Miller KD, Jemal A. Cancer statistics. 2016. Cancer J Clin. 2016; 66(1):7-30.

5. Maisonneuve P. Epidemiology and burden of pancreatic cancer. La Presse Médicale. 2019;48(3):e113-e23.

6. McIntyre A, Ganti AK. Lung cancer - a global perspective. Journal of surgical oncology. 2017;115(5):550-4.

7. Martín-Sánchez JC, Lunet N, González-Marrón A, Lidón-Moyano C, MatillaSantander N, Clèries R, et al. Projections in breast and lung cancer mortality among women: A Bayesian analysis of 52 countries worldwide. Cancer research. 2018;78(15):4436-42.

8. Lavranos Y, loannis P. Phytochemicals and chemotherapy: nove chemopreventative treatment approach in cancer, a mini review Int J Scientific Res. 2019:8(7):1-5.

9. Sakaguchi S. Regulatory T. cells: key controllers of immunologic selftolerance. Cell. 2000;101(5):455-8.

10. Zou W. Regulatory T cells, tumour immunity and immunotherapy. Nat Rev Immunol. 2006;6(4):295.

11. Tang Q, Bluestone JA. The Foxp3 + regulatory T cell: a jack of all trades, master of regulation. Nature immunology. 2008;9(3):239.

12. Beyer M, Schultze JL. Regulatory T cells in cancer. Blood. 2006;108(3):804-11.

13. Curiel TJ, Coukos G, Zou L, Alvarez X, Cheng P, Mottram P, et al. Specific recruitment of regulatory $T$ cells in ovarian carcinoma fosters immune privilege and predicts reduced survival. Nature medicine. 2004;10(9):942.

14. Prabhala RH, Neri P, Bae JE, Tassone P, Shammas MA, Allam CK, et al. Dysfunctional T regulatory cells in multiple myeloma. Blood. 2006;107(1): 301-4.

15. Kordasti SY, Ingram W, Hayden J, Darling D, Barber L, Afzali B, et al. CD4 + CD25high Foxp3 + regulatory T cells in myelodysplastic syndrome (MDS). Blood. 2007;1 10(3):847-50.

16. Schneider-Hohendorf T, Rossaint J, Mohan H, Böning D, Breuer J, Kuhlmann T, et al. VLA-4 blockade promotes differential routes into human CNS involving PSGL-1 rolling of T cells and MCAM-adhesion of TH17 cells. J Exp Med. 2014;211(9):1833-46.

17. Corselli M, Crisan M, Murray IR, West CC, Scholes J, Codrea F, et al. Identification of perivascular mesenchymal stromal/stem cells by flow cytometry. Cytometry Part A. 2013;83(8):714-20.

18. Wang Z, Yan X. CD146, a multi-functional molecule beyond adhesion. Cancer letters. 2013;330(2):150-62.

19. Tu T, Zhang C, Yan H, Luo Y, Kong R, Wen P, et al. CD146 acts as a novel receptor for netrin-1 in promoting angiogenesis and vascular development. Cell research. 2015;25(3):275.

20. Loges S, Clausen H, Reichelt U, Bubenheim M, Erbersdobler A, Schurr P, et al. Determination of microvessel density by quantitative real-time PCR in esophageal cancer: correlation with histologic methods, angiogenic growth factor expression, and lymph node metastasis. Clinical cancer research. 2007;13(1):76-80.

21. Wu Z, Wu Z, Li J, Yang X, Wang Y, Yu Y, et al. MCAM is a novel metastasis marker and regulates spreading, apoptosis and invasion of ovarian cancer cells. Tumor Biology. 2012;33(5):1619-28.
22. Wu G-J, Dickerson EB. Frequent and increased expression of human METC AM/MUC18 in cancer tissues and metastatic lesions is associated with the clinical progression of human ovarian carcinoma. Taiwanese Journal of Obstetrics Gynecology. 2014;53(4):509-17.

23. Wu G-J, Zeng G. -f. METCAM/MUC18 is a novel tumor and metastasis suppressor for the human ovarian cancer SKOV3 cells. BMC Cancer. 2016;16(1):136.

24. Zeng P, Li H, Lu P-H, Zhou L-N, Tang M, Liu C-Y, et al. Prognostic value of CD146 in solid tumor: A Systematic Review and Meta-analysis. Scientific reports. 2017;7(1):4223.

25. Wu G-J. Resolving the controversial role of METCAM/MUC18 in the progression of human breast cancer. Breast, Cervical and Prostate Cancer. Brisbane: Hard Cover; iConcept Press Ltd; 2014. pp. 87-100.

26. Wu G-J. Dual Role of METCAM/MUC18 Expression in the Progression of Cancer Cells. Gene Expression and Regulation in Mammalian CellsTranscription From. General Aspects: IntechOpen; 2018.

27. Sharma R, Thakur GS, Sanodiya BS, Savita A, Pandey M, Sharma A, et al. Therapeutic potential of Calotropis procera: A giant milkweed. ISOR J Pharm Bio Sci. 2012;4(2):42-57.

28. Pandey A, Swarnkar V, Pandey T, Srivastava P, Kanojiya S, Mishra DK, et al. Transcriptome and metabolite analysis reveal candidate genes of the cardiac glycoside biosynthetic pathway from Calotropis procera. Scientific reports. 2016;6:34464.

29. Mascolo N, Sharma R, Jain S, Capasso F. Ethnopharmacology of Calotropis procera flowers. J Ethnopharmacol. 1988;22(2):211-21.

30. Juncker T, Cerella C, Teiten M-H, Morceau F, Schumacher M, Ghelfi J, et al. UNBS1450, a steroid cardiac glycoside inducing apoptotic cell death in human leukemia cells. Biochem Pharmacol. 2011;81(1):13-23.

31. Yiallouris A, Patrikios I, Johnson EO, Sereti E, Dimas K, De Ford C, et al. Annonacin promotes selective cancer cell death via NKA-dependent and SERCA-dependent pathways. Cell death disease. 2018:9(7):1-13.

32. Dewan $\mathrm{S}$, Sangraula $\mathrm{H}$, Kumar V. Preliminary studies on the analgesic activity of latex of Calotropris procera. J Ethnopharmacol. 2000;73(1-2):307-11.

33. Nascimento T, Oki Y, Lima D, Almeida-Cortez J, Fernandes GW, Souza-Motta C. Biodiversity of endophytic fungi in different leaf ages of Calotropis procera and their antimicrobial activity. Fungal ecology. 2015;14:79-86.

34. Sharma P, Sharma J. Evaluation of in vitro schizontocidal activity of plant parts of Calotropis procera - an ethnobotanical approach. J Ethnopharmacol. 1999;68(1-3):83-95.

35. Zhishen J, Mengcheng T, Jianming $W$. The determination of flavonoid contents in mulberry and their scavenging effects on superoxide radicals. Food Chem. 1999;64(4):555-9.

36. Oyaizu M. Studies on products of browning reaction prepared from glucose amine products derived from bees. J Pharm Biomed Anal. 1986:41:1220-34.

37. Nabavi S, Ebrahimzadeh M, Nabavi S, Hamidinia A, Bekhradnia A. Determination of antioxidant activity, phenol and flavonoids content of Parrotia persica Mey. Pharmacologyonline. 2008;2:560-7.

38. Ebrahimzadeh M, Nabavi S, Nabavi S. Antioxidant activities of methanol extract of Sambucus ebulus L. flower. Pakistan journal of biological sciences. 2009;12(5):447.

39. Halliwell B. Oxidants and human disease: some new concepts. FASEB J. 1987;1(5):358-64.

40. Adaramoye O, Olajuyin AA, Comparative. In Vitro Study on the Antioxidant and Anti-acetylcholinesterase Properties of Aerial Parts of Strophanthus preusii Engl \& Pax. West Indian Med J. 2014;63(5):408.

41. Kristiansen G, Yu Y, Schlüns K, Sers C, Dietel M, Petersen I. Expression of the cell adhesion molecule CD146/MCAM in non-small cell lung cancer. Analytical cellular pathology. 2003;25(2):77-81.

42. Zhang X, Wang Z, Kang Y, Li X, Ma X, Ma L. MCAM expression is associated with poor prognosis in non-small cell lung cancer. Clin Transl Oncol. 2014; 16(2):178-83.

43. Oka S, Uramoto H, Chikaishi Y, Tanaka F. The expression of CD146 predicts a poor overall survival in patients with adenocarcinoma of the lung. Anticancer research. 2012:32(3):861-4

44. Mahomoodally MF, Gurib-Fakim A, Subratty AH. Antimicrobial activities and phytochemical profiles of endemic medicinal plants of Mauritius. Pharm Biol. 2005;43(3):237-42

45. Kumar S, Pandey AK. Chemistry and biological activities of flavonoids: an overview. Sci World J. 2013;162750(29):1-16

46. Bhandari MR, Kawabata J. Organic acid, phenolic content and antioxidant activity of wild yam (Dioscorea spp.) tubers of Nepal. Food Chem. 2004;88(2):163-8.

47. Weinberg J, Misukonis M, Shami P, Mason S, Sauls D, Dittman W, et al. Human mononuclear phagocyte inducible nitric oxide synthase (iNOS): analysis of 
iNOS MRNA, iNOS protein, biopterin, and nitric oxide production by blood monocytes and peritoneal macrophages. Blood. 1995;86(3):1184-95.

48. Moncada S, Higgs A. The L-arginine-nitric oxide pathway. New England journal of medicine. 1993;329(27):2002-12

49. Sarit B-S, Lajos G, Abraham D, Ron A, Sigal F-B. Inhibitory role of kinins on microglial nitric oxide and tumor necrosis factor-a production. Peptides. 2012;35(2):172-81.

50. Gülçin I, Elmastaş M, Aboul-Enein HY. Determination of antioxidant and radical scavenging activity of Basil (Ocimum basilicum L. Family Lamiaceae) assayed by different methodologies. Phytotherapy Research: An

International Journal Devoted to Pharmacological Toxicological Evaluation of Natural Product Derivatives. 2007;21(4):354-61.

51. Gülçın I, Oktay M, Kıreçcı E, Küfrevıoğlu Öl. Screening of antioxidant and antimicrobial activities of anise (Pimpinella anisum L.) seed extracts. Food Chem. 2003;83(3):371-82.

\section{Publisher's Note}

Springer Nature remains neutral with regard to jurisdictional claims in published maps and institutional affiliations.

\section{Submit your manuscript to a SpringerOpen ${ }^{\circ}$ journal and benefit from:}

- Convenient online submission

- Rigorous peer review

- Open access: articles freely available online

High visibility within the field

- Retaining the copyright to your article

Submit your next manuscript at $\boldsymbol{\nabla}$ springeropen.com 